\title{
Development Policy in Thailand: From Top-down to Grass Roots
}

\author{
Matthew Kelly ${ }^{1}$, Phattaraphon Yutthaphonphinit ${ }^{2}$, Sam-ang Seubsman ${ }^{1,3}$ \& Adrian Sleigh ${ }^{1}$ \\ ${ }^{1}$ National Centre for Epidemiology and Population Health, Australian National University, Canberra, Australia \\ ${ }^{2}$ Research and Development Institute, Sukhothai Thammathirat Open University, Nonthaburi, Thailand \\ ${ }^{3}$ School of Human Ecology, Sukhothai Thammathirat Open University, Nonthaburi, Thailand \\ Correspondence: Matthew Kelly, National Centre for Epidemiology and Population Health, Australian National \\ University, Bldg 62 Mills Rd, ACT 0200, Canberra, Australia. Tel: 61-2-6125-0714. E-mail: \\ matthew.kelly@anu.edu.au
}

Received: July 11, 2012 Accepted: July 27, 2012 Online Published: October 18, 2012

doi:10.5539/ass.v8n13p29 URL: http://dx.doi.org/10.5539/ass.v8n13p29

\begin{abstract}
Top-down industrial development strategies initially dominated the developing world after the second World War but were eventually found to produce inequitable economic growth. For a decade or more, governments and international development agencies have embraced the idea of participatory grass roots development as a potential solution. Here we review Thailand's experience with development strategies and we examine the current focus on participatory approaches. Thai government planning agencies have adopted "people centred development" and a "sufficiency economy", particularly emphasised since the disruptions caused by the 1997 Asian financial crisis. They aim to address the inequitable sharing of the benefits of decades of rapid growth that was particularly unfair for the rural poor. Thai policies aim to decentralise power to the local level, allowing civil society and Non-Governmental Organisations (NGOs) more of a voice in national decision making and promoting sustainable farming practices aimed at enriching rural communities. An example of this change in Thai government policy is the Community Worker Accreditation Scheme which is aiming to develop human resources at the local level by training community based leaders and supporting networks of community organisations. This enables autonomous local development projects led by trained and accredited individuals and groups. The political tensions notable in Thailand at present are part of this modern transition driven by conflicting models of top-down (industrial) development and the bottom-up (participatory) development ideals described above. Once resolved, Thailand will have few obstacles to moving to a new economic level.
\end{abstract}

Keywords: development theory, development policy, Thailand, developing countries, participatory development

\section{Background}

Development theory and practice has evolved rapidly over the last century and the current emphasis places a high premium on participatory approaches. Here we review the evolution of development theory first with a global assessment followed by a focus on Thailand. This country has often been seen as a model because it has retained much of its traditions while adopting development practices that have succeeded economically and lifted the nation from its poor agrarian background to become a modern industrialised Southeast Asian state. In this paper we pay particular attention to the distinctive mixing of grassroots community development promoted by the Royal Thai Government with export driven industrial development now being supplemented by the rise of a service economy. We aim to understand Thailand's current situation and anticipate future challenges.

Since the end of World War Two, accompanied by decolonisation of Asia and Africa effort began to improve the economic and social quality of what came to be known as the "Third World" through the new field of "development economics". What exactly constitutes development is viewed differently by different actors as is the best course to take to get to developed country status. The earliest approaches to development were based on two related concepts; development leading to modernity and development as an economic process. Both of these concepts were based on the development experience of western nations especially Western Europe and the science of economics as developed in these western contexts (Willis, 2005).

This process of development generally proceeded under the assumptions of what is referred to as neoclassical economics, the economic paradigm of the last century. This economic system rests on the theory that the best path to development is to industrialise, accumulate capital and mobilise underemployed manpower. This is 
intended to lead to growth in Gross Domestic Product (GDP) as evidence of economic progress (Stiglitz, 2002; Sen, 1992). The distribution of this economic growth and improvement in quality of life factors is not the concern of this concept of development; the assumption is that overall growth in the economy will eventually benefit everybody in it (Naqvi, 1993; Sen, 1992). At the local or community level this approach has meant that development projects have had their aims incorporated as part of this larger national project. Projects are conceived, managed and funded from outside and they have generally had the overarching aim of integrating communities into the modern commercial economy. The needs and particularities of individuals and communities are then considered less important than the process of national economic development (McGee, 2002).

Problems began to be seen with this approach to development at least at the local level from the 1970's. This criticism of top down development strategies was mainly begun by NGO's, particularly those working on development projects in communities at the grass roots level. These development workers began to see that the economic growth that was occurring in many developing countries was being unevenly distributed and particularly not improving the lives of those living in rural areas. Economic growth was in fact to some extent leading to dual economies where a more technologically advanced industrial sector, often urban based, coexists with an often rural less advanced sector with lower incomes and health status (Stiglitz, 2002). This was accompanied by an increasing concern with self-sufficiency and empowerment in community development. The idea being that giving communities a chance to analyse their own situations and problems and to help design solutions would lead to more appropriate development strategies and also to more sustainable development as the targets of the development project have decided the direction of that project and will have more of a stake in keeping it going (Mcgee, 2002).

The importance of participation in development has been perhaps most prominently promoted by Robert Chambers in his series of influential papers on "Participatory Rural Appraisals" (Chambers, 1994a,b,c). Inspired by the writings of Paolo Freire in the 1960s, particularly the Pedagogy of the Oppressed, Chambers synthesised his experience of working in international development in many areas of the world and emphasised the importance of "activist participatory research". This meant reversing the traditional process of outsiders researching the development problems and needs of communities, to one where local people informed outsiders of their needs. In Chambers view people, particularly the disadvantaged marginalised populations, needed to be given the ability to analyse their own realities and to find solutions to their own problems, with an emphasis on group based learning and planning and consensus decision making. Development practitioners would then act as facilitators of development rather than extractors of information and knowledge. When these alternative theories began to gain prominence in the 1980 s they explicitly challenged traditional power structures between state and other aid and development bodies and local communities and for this among other reasons they did not become mainstream for some time.

By the 1990's however these concerns about the effectiveness of development as it had been conceived until then were expressed also by large international and national aid organisations such as the United Nations Development Agency and the World Bank. A prominent early example of the World Bank's concern with incorporating the voices of the poor in formulating development strategies can be found in the their World Development report 2000/1: Attacking Poverty (World Bank, 2000) This change in direction from larger aid bodies was partly driven by concerns regarding the efficiency of development projects; it appeared that making local communities have a stake in the success of development projects made them more effective and efficient (Mcgee, 2002). It was also noted that the countries with the most democratic participatory systems were also the most developed and that ignoring participation issues in developing countries may actually hinder their development (Riviera-Batiz, 2002).

By the mid 1990's then the value of incorporating local voices into the development planning process in what is generally referred to as "participatory development", was accepted by most major actors in the field (Missingham, 2001). The aim of this type of development is that local people will gain greater access to state resources involving therefore a change in power relations. Efforts to implement participatory development have then involved differing levels of outsider control as this change in power relations is often resisted (Missingham, 2001). The ultimate aim however is that the development process is also a learning and social capital building project which will enable development to be sustainable as communities develop the skills to keep it going themselves. This has been combined with a more interventionist approach in regards to governance by international organisations with concern for human rights and civil society strengthening becoming more important leading to a convergence of the development and human rights agendas (Mcgee, 2002).

Many criticisms have however been raised over the effectiveness and real impacts that "participatory" methods 
have on the development process, particularly since the mainstreaming of "participation" in the mid to late 1990s. One of the major concerns of critics is that once mainstream development agencies adopted participatory practices the empowerment aspect of these practices was dissipated. That is the overall national and international development strategies which aim to increase the size of the modern capitalist economy within countries remain dominant. Rural and poor groups who are asked to participate in their development are still not able to negotiate the fundamental political power structures and economic paradigms under which they live. (Kothari, 2001). People are perhaps being "empowered" to participate in the modern capitalist economy rather than actually being empowered to make their own decisions regarding economic development (Henkel \& Stirrat, 2001). One possible way to alleviate this limitation of participatory development as currently practiced may be to encourage development initiatives which as well as improving the material livelihoods of communities also aim to improve the political capabilities of marginalised groups. This could perhaps include encouraging participation in local governance leading to a more balanced interaction with the state and more awareness of political rights, although this would obviously depend on the local political contexts (Williams, 2004).

Another commonly voiced criticism of "participatory development", particularly as it is framed by more grass roots development practitioners is the idealising of the idea of "community" with its supposedly shared local culture and shared goals. This may often obscure the significant power differentials and social conflicts which may occur at the local level. These include unequal relationships based on gender, class ethnicity or other factors (Williams, 2004). Allowing open communication and consensus decision making without rules and formal structures may merely leave dominant members of the group in the same position (Kapoor, 2002).

\section{The Thai Experience}

Thailand is a country which has achieved a rapid and fundamental process of economic development and social change with an average GDP growth of around 7\% and real per capita incomes tripling in the last 25 years. Overall the quality of life and human security of the population has been dramatically improved with poverty levels falling from almost half the population to around $8 \%$ today. Large improvements have been made in most health indicators with infectious disease and malnutrition levels falling and access to medical care improving through the introduction of a Universal Coverage Scheme. Here we examine how the gradual growth in the importance globally of "participatory development" practices have been incorporated into the Thai experience and outline one example of this development theory in practice in Thailand; the Community Worker Accreditation Scheme.

Through the second half of the $19^{\text {th }}$ century and the early $20^{\text {th }}$ century Thai monarchs slowly began a process of modernising and developing the kingdom. Although economic growth in the Western sense was largely absent in this period along with technological advances this era had some features which had far reaching effects into the modern era. These include: the beginning of a promotion of agricultural production for export; the reform of slavery and corvee labour systems to enable free labour; tax and other incentives for productive land settlement; investment in infrastructure; and the strengthening and centralising of public administration (Muscat, 1994). These economic changes produced a domestic environment which was more stable than in the past, and where greater control over land and labour led to significant demographic growth and geographic dispersal of the Thai population (Carmichael, 2008). This process however had limitations and stagnated through the World War II period and the changes in administration which preceded and followed the war.

The process of intensive economic development really only began in Thailand with the ascension to power of Sarit Thannarat in 1958. Under a non-elected bureaucratised leadership development focused on agricultural intensification accompanied by increased industrialisation and a move towards an export oriented economy (Darlington, 2000). "Development" became the symbol of legitimacy for an authoritarian national government and Sarit launched Thailand's first 5-year National Economic and Social Development Plan (NESDP) in 1961; this first plan ushered in an historical period lasting several decades and referred to as the "era of development" (Baker \& Phongpaichit, 2005). The 1961-66 plan linked Thai development to economic growth led by private-capital. This model involved a team of Thai technocrats working in cooperation with the World Bank and other Western advisers to make the macroeconomic changes needed to bring about rapid development, focusing first on infrastructure and agricultural extension (Muscat, 1994).

Change was rapid and commercialisation of the agricultural economy soon affected a large proportion of the population. Although change affected the whole population this was a clear attempt at top-down trickle down development. No policy was made regarding the equal distribution of this growth. Investment was particularly aimed at those areas with the most potential for economic growth thus aiding those already more well off. The centralised nature of development policy was also a strong feature. Local participation in development decision 
making was almost non-existent (Parnwell, 1996). Where attempts were made at gaining the approval of communities for development projects this was only done through village heads who worked as middle men between communities and the government development workers (Karnjanaprakorn, 1965). Some consequences were the rise of a rural elite who took advantage of more money being present in the rural economy, a growing economic inequality between rural and urban groups and within these groups, and as a consequence a large increase in rural-urban migration.

By the late 1960s however national economic planning had moved away from the agricultural sector in favour of urban industrial growth. Growth in agricultural production was not seen as sufficient to produce the desired economic growth and investment in agricultural infrastructure fell as did the agricultural share of GDP. Aided by foreign investment actively promoted by the 1960 Promotion of Investment Act, the urban economy grew rapidly as the rural one shrank leading to an ever greater flow of migration to urban areas. US aid and foreign investment in this period combined with the dominant modernisation paradigm followed by the Thai government led to the use of agricultural surpluses to fund industrial expansion at the same time as neglecting the standards of living of rural dwellers themselves. This process was modified somewhat following the growth of the short lived communist linked rural rebellion in the 1970 s but new rural policies were aimed at further commercialisation of agriculture including the beginning of the food processing and agricultural industry that would become so important to the Thai economy in the 1990s and to the present day (Goss and Burch, 2001).

Although the economy was growing at a rapid rate particularly by the 1980s the gap between rich and poor was also growing. In fact Thai development policy was seen as having contributed to rural impoverishment (Scmidt,1996). The same groups who were already better off benefitted the most. As well as these economic inequalities the centralised nature of development also meant that local cultures and regional diversity were devalued (Darlington, 2000). Education was conducted in the Central Thai language and an active nationalist campaign was conducted which aimed to increase national loyalty, centralise power in Bangkok and decrease the autonomy of the regional centres (Jory, 1999).

\subsection{NGO Movement and "Alternative Development"}

The change in the focus of development activities discussed generally in the proceeding section has also taken place in Thailand. As early as the late 1960s prominent Thai academics and some public servants were criticising the development path being taken by Thailand and considering ways in which the benefits of economic growth could be shared more equally by all sectors of Thai society. Several organisations were established in the early 1970 's to attempt to initiate a process of community development at the local level which was participatory in nature. Through the early 1970's these movements slowly grew along with disillusionment with the growth oriented development policies as well as the military governments which held power. This process quickened after the 1973 mass demonstrations which led to the temporary end of military rule in Thailand. Student activists and other groups began to travel to rural areas and initiate a process of both rural community development and human rights work. The crackdown and return to military rule in 1976 made these rural development activities more difficult (Quinn, 1997).

By the mid 1980's the political atmosphere had changed again and more open politics and amnesties for communist groups were accompanied by an explosion in the number of rural development NGOs operating in the kingdom. With encouragement and assistance from international NGOs many Thai social activists again returned to focus on the needs of those being left behind in Thailand's rapid economic growth, the disadvantaged in rural areas primarily. These NGOs saw the connection between lack of political voice and economic disadvantage and began to push for more participation in development planning from rural communities themselves in the absence of participatory democracy at the national level (Quinn, 1997). This has come to be seen as an "alternative development" path in the Thai context as it challenged the centralised paternalistic power of the entrenched bureaucracies in Bangkok. Popular participation in development aimed at not only improving material wellbeing but giving communities more power over their resources and giving them a bigger voice in the political context (Turton, 1987; Jumbala, 1987). Locality specific projects also became more important rather than broad national strategies which did not adapt to local conditions. The concept of "local wisdom" (phuum panyaa) became popularised as a sort of deep knowledge of the locality that Bangkok bureaucrats could not emulate. This was termed a "community culture" (watthanatham chumchon) approach to development (Nartsupha, 1991).

One other interesting aspect of this period of growth in NGOs and alternative development theories is the growing concern shown by Buddhist monks, particularly in rural areas, over the impact of the government's development path on rural communities. Individual monks working outside their established organisational 
structure began instituting alternative development programs. These self proclaimed "development monks" (Phra Nak Patthana) worked at the local level to alleviate specific problems identified by communities. Some of these monks actually established their own NGOs to assist in rural grassroots development (Darlington, 2000).

Despite this growing movement there have also been many critics of these grassroots development NGOs. Some of their criticisms include: 1) they aim to separate communities from the state and the market which is unrealistic and unsustainable in the modern era, 2) they do not have an analytical understanding of the broader picture of industrialisation and economic change as they focus at the individual community level, 3) NGOs are influenced by the agrarian myth of the past, 4) NGOs are only relevant to remote rural areas; their ideologies will not work in urban areas (Quinn 1997). Also although they have often had a positive impact within communities their impact has been fragmented and local issue based. It wasn't until 1991 that rural advocacy NGOs were given a voice in national decision making (Muscat, 1994).

Possibly the biggest success of the Thai NGO movement since the 1980s has been achieved when Rural People's Organisations (Ongkorn Prachachon Chanabot) have worked together with the relevant government agencies, including agricultural extension agents and workers from the Community Development Department of the Ministry of Interior. This enabled community needs to be clearly identified while government resources were mobilised within a national framework (Garforth \& Suthsupa, 1996). Informal grassroots organisations have been instrumental in turning government policy into action since the first development plan in 1961. Government policies which have been effective have always been filtered through pre-existing informal organisations, often via the village chief (Karnjanaprakorn, 1965).

\subsection{The Broader Thai Context}

This growth in NGOs occurred amidst a growing civil society, a general democratisation and an opening of political space for opposition to dominant political views in the nation. Since at least the mid-80's there has been a movement to decentralise political power and ensure popular participation in economic and social development (Phongpaichit, 1999). By the late 1990s Thailand was clearly moving away from unitary governance to a more pluralistic system. Examples include the creation of autonomous central bodies such as the Election Commission and the National Anti-Corruption Commission, and devolution of decision making responsibilities to governments at the local level (Bowornwathana, 2006). Thailand has traditionally had strongly centralised government with a dominant bureaucracy so these pluralistic changes are being resisted by elements within this bureaucracy who stand to lose some influence if power is devolved. This can particularly be manifest by local representatives of the national bureaucracy whose role it is to implement changes (Phongpaichit, 1999; Rigg, 1991).

The peak planning body in Thailand, The National Economic and Social Development Board (NESDB), has been mostly responsible for this new policy direction. Its 5-year National Economic and Social Development Plans (NESDPs), since at least the $5^{\text {th }}$ plan (1982), included the aim of popular participation in development and the more equitable distribution of the benefits arising from economic development (Muscat, 1994). A holistic approach to development and quality of life was taken meaning not just achieving good health but achieving Basic Minimum Needs (BMN) in all aspects of life for all individuals in society. Main goals for community development were: 1) adequate food and nutrition 2) proper housing and environment 3) adequate health and basic education 4) security and safety 5) family food production 6) family planning 7) people's participation in community development and 8) spiritual or ethical development. An important BMN strategy was community finance of development projects to increase community self-reliance (Tontisirin et al., 1999; Tontisirin \& Winichagoon, 1999). There were many successful NESDB development measures carried out through the 1980s and 90 s including village based health care centres, improved nutrition, widespread potable water, and much better sanitation. Critics still point to the shortcomings of this era because it ignored internal inequalities within villages and, as with many other top-down development strategies, benefitted most those already better off within communities (Muscat, 1994).

One of the major signs of changes in Thailand's political system was the growing power of "people's movements" for political change which culminated in the 1997 "people's constitution". Under the leadership of leading reformist and academic Prawase Wasi this reform process aimed to draw in people from all parts of the population to contribute to political change. For the first time, the debate on political reform in Thailand now included NGOs and civil society actors who had previously been left out (McCargo, 2001). These changes also had an impact on how the Thai government approached development policy with more attention being paid to decentralised decision making and popular participation in development. An important part of this decentralisation strategy was the creation of Tambon Administrative Organisations (Tambon is a unit of 
administration commonly referred to as a sub-district). These organisations had more power than ever before to control funding priorities and development policies at the local level (Parnwell, 2005). Alternative development theories and localism, as described above in the section on NGO movements, now became mainstream and the ideal of self-sufficient agricultural communities entered the national discourse (McCargo, 2001).

Particularly since the 1997 Asian financial crisis the focus of central development policy makers has turned to promoting a development goal known in English as a Sufficiency Economy (SE) or setthakit phor phiang. This goal, which equates with much of what "alternative development" supporters had been promoting, emphasises moderation and a middle path between capitalist excess and rural deprivation and aims to encourage people to develop self discipline in consumption. Farming communities are encouraged to diversify their production and enhance their self sufficiency. The emphasis is on not growing just one product for the market but instead combining growing a variety of cash crops with fruits and vegetables for household consumption as well as practicing low chemical sustainable agriculture. This agriculture aims to restore farmland degraded by chemical use and erosion and increase the cash incomes of farmers as they grow a larger variety of crops, reducing vulnerability to the fluctuations of the market. The SE operates at 3 levels: households self-sufficient in food; communities self-sufficient through cooperative trade, labour and finance; and regions (and the nation) forming cooperative trade networks (Sathirathai \& Piboolsravut, 2004). SE is intended for the community, region and national level, although to date most activity has been for rural community development. Partly because of the support of the Thai monarch for this approach to development, top Thai development policy makers under the support of the Thailand Development Research Institute (TDRI) began analysing and implementing these SE ideas (McCargo, 2001).

The aim of development policy now is the creation of "Balanced Human Centred Development". The $9^{\text {th }}$ NESDP covering the years 2002-2006 has the stated objective of producing "Enduring Development and Improvement in the Happiness of the Thai People". SE ideals were used, being applied in the fields of economics, social processes, politics and the environment. Lead Thai policy makers aimed to produce strong self-reliant communities at the local and national level which could compete with the outside world while retaining their Thai identity (National Economic and Social Development Board, 2002).

Truly participatory development in Thailand still confronts several problems. These schemes are formulated in Bangkok and they can still be seen as top-down strategies for development. Many of the economists who have now turned to supporting the SE and Localism principles are the same people who promoted capitalist industrialisation driven development until the 1990s (McCargo, 2001). Outside the government sphere, although there has been an enormous growth in civil society groups over the last 20 years in Thailand, most of these groups have been dominated by urban based middle-class academics and NGOs. So the driving force for changes in policy in favour of localism and grass roots development have not actually come from the localities themselves (Parnwell, 2005). Also, multiple actors are responsible for community development and Ministries and Departments are still able to make independent decisions on how this occurs. Furthermore, development work often involves only village leaders who are then responsible for organising community members to take part. "Popular participation" has more often been actually a "mass mobilisation" due to the hierarchical socio-political relations which exist at the local level (Rigg, 1991).

There have however been some government sponsored schemes which do attempt to address the lack of a real forum for local community voices in national debate. One of these is the Community Work Accreditation Scheme developed by academics and community development workers from the Community Development Department and Sukhothai Thammathirat Open University. This scheme is described as a case study of a modern development method now being supported in Thailand.

\subsection{The Community Work Accreditation Scheme (CWAS)}

In recent years community leaders, NGO's and the Community Development Department (CDD), within the Ministry of Interior, as well as other relevant government agencies have been developing a system to help train and develop human resources at the local level enabling community empowerment and a sustainable development which is driven from the community level. This system is called the "Community Work Accreditation System" (CWAS) and it was put together by a committee of government and civil society representatives. The scheme is designed to work at 4 levels with separate programs being developed for community leaders, community organisations, networks of community organisations and community members themselves. Groups or individuals would apply to be part of the program and once accepted would begin working with representatives of the CDD.

The aim of the scheme was to improve human resources at the community level to enable project planning, 
administration, and budgeting and finance, as well as project evaluation and modification, all to occur within communities and networks of community organisations reducing reliance on central planning and development agencies. Key to this was helping these community leaders develop processes by which development needs could be identified, benchmarks for measuring progress set and accountable administration and evaluation processes established. These community members would receive training and work in collaboration with members of the CDD in order to receive their accreditation. Ongoing work would still be subject to evaluation and approval by the Department but communities would be given more autonomy in their operations.

The CWAS had the following essential components: it had to include community involvement, the community had to be able to develop a sense of ownership of the development process, the local people had to derive the benefits of development projects proposed, community involvement had to be voluntary, development processes had to suit the local conditions of each community and all development work had to be participatory at all stages and levels with the government providing support only.

The implementation of the scheme was as follows:

1) Building understanding/awareness and attracting volunteers - Community development workers with knowledge of the CWAS organised public forums in the target communities to facilitate knowledge sharing between the community members and government staff as well as giving community members an initial understanding of the CWAS. Volunteer communities then applied to join the accreditation program.

2) Situation analysis - the strengths and weaknesses of current development strategies and the current development needs of each targeted community were then assessed.

3) Setting target achievements - Community network members collectively developed objective targets as part of a consultative process involving all CWAS participants. These targets were then assessed for their achievability, accordance with local conditions and appropriateness for the stated goal of achieving knowledge and competency among members. Targets were then adjusted according to those criteria.

4) Organising a self-development plan - Community forums were held to collectively develop processes to be followed to achieve the decided targets.

5) Learning process - after a plan was established the members began the actual process of skill development, knowledge sharing and improvement and ability development.

6) Evaluation - The evaluation process had 2 parts. Firstly throughout the accreditation period community members performed self-evaluations of the progress being achieved by following the self-identified development plans. Processes were therefore continuously adjusted in reaction to these evaluations. A final assessment at the end of the training period would be carried out in consultation between representatives of the Department of Community Development and community members. This assessment would have both quantitative evaluations of achievement in terms of incomes raised increases in production achieved etc and qualitative assessment through interviews with community members and community forums to ascertain how the community perceived changes and changes in community attitudes. After this a decision would be made whether to award the accreditation to that individual or group.

\subsection{Assessment of the CWAS}

After establishing the main guidelines of the CWAS the question then arose of whether an accreditation system established by a national network could really be self-empowering for the local communities involved so it was decided to conduct research at the community level to test the system's effectiveness in developing local human resources and to identify potential obstacles. Sukhothai Thammathirat Open University research staff as well as their distance learning students who reside throughout the country, particularly those already involved in community development work along with the Department of Community Development therefore began this study.

The community groups chosen for this study were 50 members of the Provincial Community Development Volunteer Club (CDVC) of Petchabun province and the Provincial Community Organisation Coordinating Centre (COCC) in Kanchanaburi province. Data were gathered over the course of one year from October 2005-October 2006 using observation, unofficial interviews and conversations as well as community forums. Collected information was then summarised in reports at the end of the study period. These reports were synthesised and examined using qualitative analysis.

The evaluation found community members and organisation had an improved ability to set appropriate targets for their work and formulate benchmarks to measure progress. This increased efficiency and gave community 
members more ownership of their projects. As well, administration of human and financial resources improved. A summary of the results of the assessment are as follows:

Table 1. Assessment of the community worker accreditation scheme

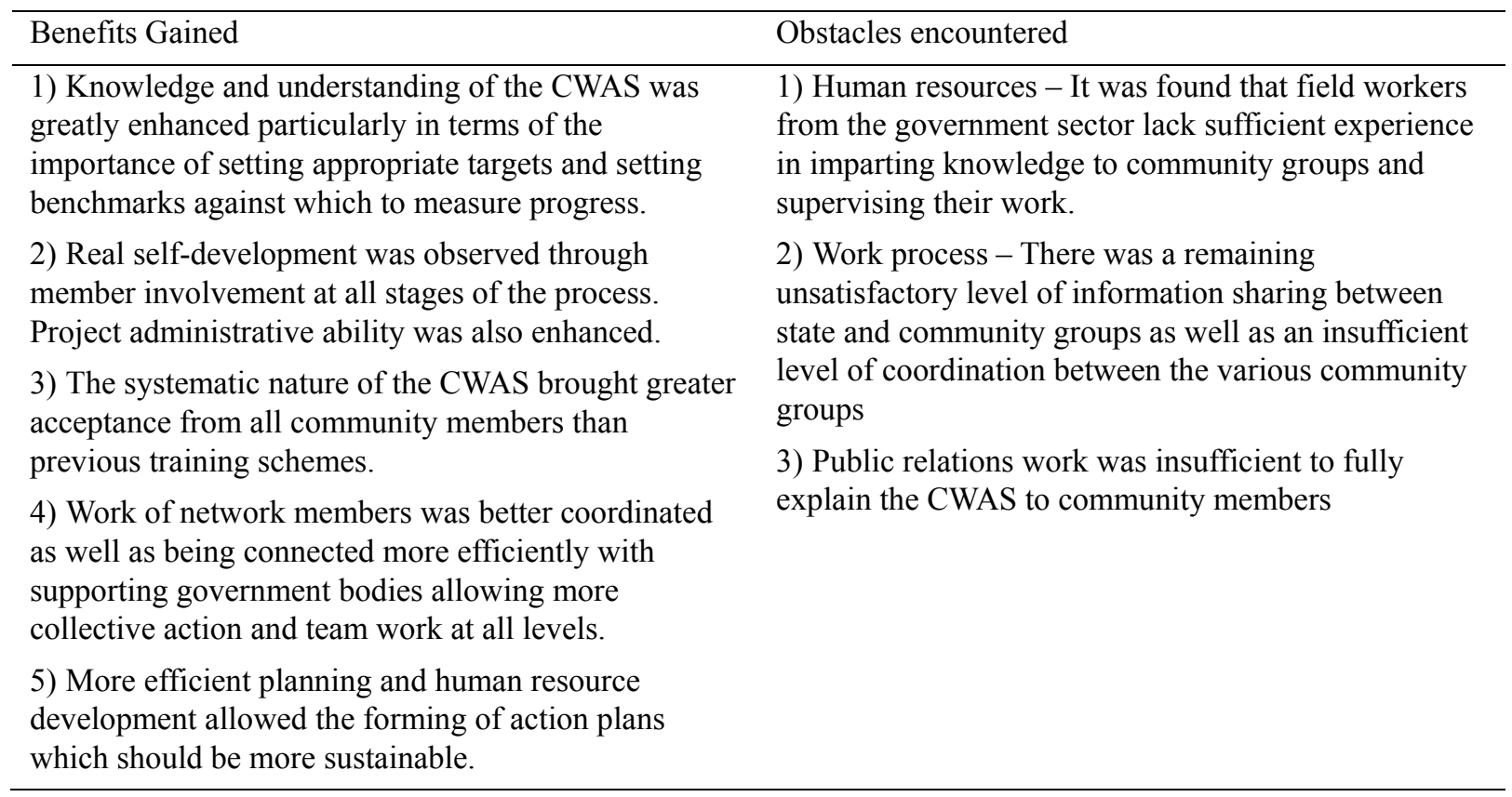

\section{Conclusions}

Development experience over many decades in Thailand has revealed that community learning and empowerment is most effective when the process is truly participatory. Outside agencies and community members each have something to offer the development process. Learning is best connected to real life activities, that is learning through collaborative action (Walaisethian, 2000). If people are responsible for their own learning they own the knowledge gained. An effective and sustainable process of national development involves giving community members' decision making power in solving their own problems. This is a large part of promoting real democracy and effectively harnessing power relations (Chuaimankong, 2006; Panyaawan, 2005).

State agencies still have an important part to play in community development. They should support and encourage community activities financially and logistically as well initiating opportunities for self-empowerment by communities and listening and encouraging their participation (Chaiyapong, 1996). The most effective development processes in Thailand however have historically been those which rely on the least amount of outside promotion and the most organic spontaneity in the creation of community development groups. Traditional community groups such as irrigation maintenance committees which have existed for centuries may be the best place to build on for development activities rather than outside actors trying to create new artificial bodies (Rigg, 1991).

Our research has found the CWAS to be an effective tool for enhancing skills, knowledge and the ability to plan within networks of community organisations which are appropriate for each individual setting. It has led to more deeply embedded learning and more collaborative and sustainable work.

One of the main problems which has been faced by proponents of real grass roots participatory development in Thailand has been the strong centralised bureaucracy which is reluctant to devolve power over decision making and funding to other levels of government. To improve participatory development more government support is needed including a formalising of the aims of community strengthening and power decentralisation through legislation. Part of this government aid should also be financial. Funds should be given to community organisations with the view that these community organisations are independent bodies whose investment strategy is not part of any government department. This will involve a potentially radical change in power relations in Thailand and for this reason will not be easy to achieve.

The development policies of the central Thai government in Bangkok have changed dramatically over the last 60 years along with changes in style of governance and attitudes towards popular participation. From the era of military dictatorship and top down development favouring rapid industrialisation and entry into a market economy often at the expense of rural communities, policy from central planning agencies now favours the 
valuing of community cultures and local participatory development projects aimed at sustainable development. These changes have occurred in parallel with changes in the political system in Thailand towards a more open democratic system with more of a role for civil society.

Overall these development strategies appear to have proven quite effective with Thailand experiencing a rapid and sustained economic growth and process of poverty reduction. Vulnerabilities still remain however, particularly for the $10 \%$ of the rural population still in poverty and for informal workers in rural and urban areas. With the rapid industrialisation of the country however economic inequality has grown steadily, particularly between urban and rural dwellers the challenge for development policy makers into the future will be to ensure rural dwellers do not get left behind and that principles of participatory development incorporated in development plans do not get left behind. (United Nations Development Programme, 2010)

Events in recent years have also revealed remaining underlying tensions within the political system with rapid changes in government and a military coup in 2006 meaning the movement towards democratisation and participatory government is not a certain one. Tumultuous events of the last years particularly, which have seen rural dwellers and urban migrants protesting against perceived uneven development and double standards in governance shows that Thailand may be at a crucial turning point in its political development. In fact the attitude which planning agencies now take towards rural development may be decisive in determining the direction of Thailand's political future. Current efforts at national reform and reconciliation led by prominent social critic Prawase Wasi aim at including land reform and decentralisation of power to the local level indicate efforts being made to address these issues. The outcome of the present struggle between rural populists and urban traditionalists may channel the tensions that have built up as a result of economic development unmatched by political reform.

\section{Acknowledgments}

This study was part of the Thai Health-Risk Transition research program supported by the International Collaborative Research Grants Scheme with joint grants from the Wellcome Trust UK (GR071587MA) and the Australian NHMRC (268055) support was also provided by the Research and Development Institute, Sukhothai Thammathirat Open University. We thank the Thai Cohort Study team for their support without which this work would not be possible.

\section{References}

Baker, C., \& Phongpaichit, P. (2005). A History of Thailand. Cambridge UK: Cambridge University Press.

Bowornwathana, B. (2006). Autonomisation of the Thai state: Some observations. Public Administration and Development, 26, 27-34. http://dx.doi.org/10.1002/pad.368

Carmichael, G. (2008). Demographic disequilibrium in early twentieth century Thailand: falling mortality, rising fertility or both? Asian Population Studies, 4(2), 161-176. http://dx.doi.org/10.1080/17441730802247265

Chaiyapong, P. (1996). Involvement of community members in maintaining their physical and environmental security: A study of Orm Noi district, Samut Sakhon province. Bangkok: Dissertation for Graduate Studies in Social Development, Institute for Graduate Studies in Development Administration.

Chambers, R. (1994a). The origins and practice of Participatory Rural Appraisal. World Development, 22(7), 953-969. http://dx.doi.org/10.1016/0305-750X(94)90141-4

Chambers, R. (1994b). Participatory Rural Appraisal: Analysis of experience. World Development, 22(9), 1253-1268. http://dx.doi.org/10.1016/0305-750X(94)90003-5

Chambers, R. (1994c). Participatory Rural Appraisal: Challenges, potential and paradigm. World Development, 22(10), 1437-1454. http://dx.doi.org/10.1016/0305-750X(94)90030-2

Chuaimankong, W. (2006). Learning process to help community leaders solve their communities' problems: A study of Baan Phran in Ang Thong province. Bangkok: Briefing document for the Department of Community Development, Ministry of Interior.

Darlington, S. (2000). Rethinking Buddhism and development: the emergence of environmentalist monks in Thailand. Journal of Buddhist Ethics, 7.

Garforth, C., \& Suthsupa, P. (1996). Who benefits from agricultural extension? Training and visits and the role of Rural People's Organisations in the upper north of Thailand. In M. Parnwell (Ed.), Uneven Development in Thailand (pp. 265-281). Brookfield, Vermont: Avebury. 
Goss, J., \& Burch, D. (2001). From agricultural modernisation to agri-food globalisation: the waning of national development in Thailand. Third World Quarterly, 22(6), 969-986. http://dx.doi.org/10.1080/01436590120099740

Henkel, H., \& Stirrat, R. (2001). Participation as spiritual duty; empowerment as secular subjection. In B. Cooke, \& U. Kothari (Eds.), Participation: the new tyranny? (pp. 168-184). London: Zed Books.

Jory, P. (1999). Political decentralisation and the resurgence of regional identities in Thailand. Australian Journal of Social Issues, 34(4), 337-352.

Jumbala, P. (1987). Interest and pressure groups. In S. Xuto (Ed.), Government and Politics of Thailand (pp. 132-162). London: Oxford University Press.

Kapoor, I. (2002). The devils in the theory: a critical assessment of Robert Chamber's work on participatory development. Third World Quarterly, 23(1), 101-117. http://dx.doi.org/10.1080/01436590220108199

Karnjanaprakorn, C. (1965). The role of informal organisations in community development: the Thai experience. In proceedings of International Development Seminar on Community Development and Local Government, Honolulu Hawaii: East-West Center.

Kothari, U. (2001). Power knowledge and social control in participatory development. In B. Cooke, \& U. Kothari (Eds), Particiaption: the new tyranny? (pp. 139-152). London: Zed Books.

McCargo, D. (2001). Populism and reform in contemporary Thailand. South East Asia Research, 9(1), 89-107. http://dx.doi.org/10.5367/000000001101297333

McGee, R. (2002). Participating in Development. In U. Kothari, \& M. Minogue (Eds.), Development Theory and Practice (pp. 92-116). Basingstoke: Palgrave.

Missingham, B. (2001). Participatory development in Thailand: a review of some of the relevant literature. Canberra: Fenner School of Environment and Society, Australian National University. Retrieved June, 2012, from http://hdl.handle.net/1885/40082

Muscat, R. (1994). The fifth tiger: a study of Thai development policy. Helsinki: United Nations University Press.

Naqvi, S. N. H. (1993). Development Economics: A New Paradigm. New Delhi: Sage.

Nartsupha, C. (1991). The community culture school of thought. In M. Chitakasem, \& A. Turton (Eds), Thai constructions of knowledge (pp. 118-141). London: School of Oriental and African Studies, University of London.

National Economic and Social Development Board. (2002). Ninth National Economic and Social Development Plan. Bangkok: NESDB.

Panyaawan, K. (2005). Linking networks for knowledge sharing and training: A study of the Health worker network of Phrae province. Bangkok: Dissertation for Graduate Studies in Community Development, Thammasat University.

Parnwell, M. (1996). Uneven Development in Thailand. Brookfield, Vermont: Avebury.

Parnwell, M. (2005). The power to change: Rebuilding sustainable livelihoods in North-East Thailand. The Journal of Transdisciplinary Environmental Studies, 4(2). Retrieved from http://www.journal-tes.dk/vol_4_no_2/NO4_MI_1.PDF

Phongpaichit, P. (1999). Civilising the state: state, civil society and politics in Thailand. Amsterdam: Center for Asian Studies.

Quinn, R. (1997). NGOs, Peasants and the State: Transformation and Intervention in Rural Thailand, 1970-1990. Canberra: PhD thesis, the Australian National University.

Rigg, J. (1991). Grass-roots development in rural Thailand: A Lost Cause? World Development, 19(2-3), 199-211. http://dx.doi.org/10.1016/0305-750X(91)90255-G

Riviera-Batiz, F. L., \& Riviera-Batiz, L. A. (2002). Democracy, Participation and Economic Development: an Introduction. Review of Development Economics, 6(2), 135-150. http://dx.doi.org/10.1111/1467-9361.00146

Scmidt, J. D. (1996). Paternalism and planning in Thailand: Facilitating growth without social benefits. In M. Parnwell (Ed), Uneven Development in Thailand (pp. 63-81). Brookfield, Vermont: Avebury.

Sen, A. (1992). Development: Which way now? In C. Wilber, \& K. Jameson (Eds), The Political Economy of Development and Underdevelopment (pp. 5-26). New York: McGraw Hill. 
Stiglitz, J. E. (2000). Formal and informal institutions. In P. Dasgupta, \& I. Serageldin (Eds.), Social Capital: a Multifaceted Perspective (pp. 59-70). Washington DC: World Bank.

Stiglitz, J. E. (2002). Participation and Development: perspectives from the comprehensive development paradigm. Review of Development Economics, 6(2), 163-182. http://dx.doi.org/10.1111/1467-9361.00148

Tontisirin, K., \& Winichagoon, P. (1999). Community based programmes: success factors for public nutrition derived from the experience of Thailand. Food and Nutrition Bulletin, 20(3), 315-322.

Tontisirin, K., Kachondham, Y., \& Winichagoon, P. (1992). Trends in the development of Thailand's nutrition and health plans and programs. Asia Pacific Journal of Clinical Nutrition, 1, 231-238.

Turton, A. (1987). Production, power and participation in rural Thailand: Experiences of poor farmers groups. Geneva: United Nations Research Institute for Social Development.

United Nations Development Programme. (2010). Human security, today and tomorrow: Thailand Human Development Report 2009. Bangkok: UNDP.

Walaisethian et al. (2000). Processes and techniques for development workers. Bangkok: Thailand Development Research Fund.

Williams, G. (2004). Evaluating participatory development: tyranny power and (re)politicisation. Third World Quarterly, 25(3), 557-578. http://dx.doi.org/10.1080/0143659042000191438

Willis, K. (2005). Theories and practice of development. Oxon: Routledge.

World Bank. (2000). World Development Report 2000/2001: Attacking poverty. New York: Oxford University Press. 